\title{
Effect of sow age on the apparent total tract digestibility of nutrients in the diet
}

\author{
E. Jacyno, A. Pietruszka\#, W. Biel, A. Kołodziej-Skalska, B. Matysiak, \\ M. Kawęcka \& A. Sosnowska \\ Department of Pig Breeding, Animal Nutrition and Food, West Pomeranian University of Technology in Szczecin, \\ 10 Judyma Street, 71-460 Szczecin, Poland
}

(Received 27 February 2016; Accepted 2 June 2016; First published online 31 July 2016)

\begin{abstract}
Copyright resides with the authors in terms of the Creative Commons Attribution 2.5 South African Licence.
See: http://creativecommons.org/licenses/by/2.5/za

Condition of use: The user may copy, distribute, transmit and adapt the work, but must recognise the authors and the South African Journal of Animal Science.
\end{abstract}

\begin{abstract}
The objective of this research was to evaluate the effect of sow age on apparent total tract digestibility of nutrients and the concentration of metabolizable energy in the diet. The experiment was carried out on 20 gestating sows, divided into two groups: Group I - 10 sows in first pregnancy (131 $\pm 4.5 \mathrm{~kg})$ and Group II - 10 sows in fourth pregnancy $(225 \pm 8.2 \mathrm{~kg})$. Sows in the two groups were fed identical diets for sows during early pregnancy. The total collection of faeces began on day 30 of pregnancy and lasted eight days. Sows in the fourth pregnancy had greater digestibility coefficients of dry matter (4.1 percentage units), organic matter (3.4 percentage units), crude protein (5.5 percentage units) and crude fibre (6.2 percentage units) than sows in the first pregnancy. The total tract digestibility of ether extract, starch and sugars was not affected by pig age. The metabolizable energy, determined according to the content of digestible nutrients, in the sow diet in fourth pregnancy was $0.7 \mathrm{MJ} / \mathrm{kg}$ higher than in the diet of sows in their first pregnancy. Results of this research indicate that sow age should be considered when formulating diets during early pregnancy.
\end{abstract}

Keywords: Digestibility, gestation, metabolizable energy, nutrients, age of sow

\#Corresponding author: Arkadiusz.Pietruszka@zut.edu.pl

\section{Introduction}

The apparent total tract digestibility of nutrients in pigs could be affected by many factors, among others the age and body weight of animals. Adult pigs have a more developed and larger gastro-intestinal tract with residence time of ingesta being longer than in growing pigs (Varel, 1987; Low, 1993). The slow passage rate of digesta through the large intestine supports extensive fermentation of fibre and encourages bacterial growth (Mosenthin, 1998). The number of cellulolytic bacteria in the large intestine of adult sows is 6.7 times greater than in growing pigs (Varel, 1987). This results in a greater capacity of sows to digest fibrous components and other nutrients compared with young pigs (Fernandez et al., 1986; Varel, 1987; Noblet \& Shi, 1993; Shi \& Noblet, 1993a; b; Le Goff \& Noblet, 2001; Jørgensen et al., 2007).

Digestibility of energy is the sum of the energy digestibility of protein, lipids and carbohydrates. The effect of pig age on the increased digestibility of these nutrients is due mainly to the greater rate of degradation of the fibre fraction in the large intestine (Jørgensen et al., 1995; Urriol et al., 2010). This leads to an increase in the digestibility of energy in older pigs compared with younger ones (Le Goff \& Noblet, 2001; Wilfart et al., 2007; Le Gall et al., 2009).

The effects of age and body weight (BW) on apparent total tract digestibility of nutrients and energy has been demonstrated in many experiments on growing pigs and adult sows (Fernández et al., 1986; Noblet \& Shi, 1993; Le Goff \& Noblet, 2001; Le Gall et al., 2009; Lowell et al., 2015). The objective of this research was to evaluate the effect of age in gestating sows on the apparent total tract digestibility of nutrients and the concentration of metabolizable energy (ME) in the diet of sows during early pregnancy.

\section{Materials and Methods}

A total of 20 gestating sows of the same genetic origin (Polish Large White $\times$ Polish Landrace) was used in this experiment. Three days before artificial insemination, sows were weighed and allotted to two groups, depending on age/BW: Group I - 10 sows in first pregnancy (131 $\pm 4.5 \mathrm{~kg})$ and Group II - 10 sows in the fourth pregnancy $(225 \pm 8.2 \mathrm{~kg})$. At the fifth week of pregnancy, each sow was placed in an individual metabolism cage $(0.9 \times 2.3 \mathrm{~m})$, equipped with a feeder and a nipple drinker. 
The experimental diet was formulated according to recommendations for the nutrient requirements for sows during early pregnancy of the Polish Standards of Pig Feeding (2014). The feed ingredients of the experimental diet are presented in Table 1. From insemination and during the experimental period, the sows received a diet of $2.8 \mathrm{~kg}$ per day in two equal meals at 07:30 and 17:00. During the experimental period, there were no refusals. The animals had ad libitum access to water for the entire experiment.

Table 1 Composition of experimental diet for sows during early pregnancy

\begin{tabular}{lc}
\hline Ingredients (\%) & \\
\hline Wheat & 15.00 \\
Barley & 30.00 \\
Triticale & 10.00 \\
Oats & 15.00 \\
Wheat bran & 20.00 \\
Soybean meal (47\% CP) & 7.50 \\
Lysine & 0.10 \\
DL-methionine & 0.05 \\
L-threonine & 0.05 \\
Limestone & 0.66 \\
Vitamin-mineral premix* & 0.50 \\
Dicalcium phosphate & 0.74 \\
Sodium chlorate & 0.40 \\
Total & 100.0 \\
\hline
\end{tabular}

*Provided per kilogram of complete diet: vitamin A, $15000 \mathrm{IU}$; vitamin $\mathrm{D}_{3}, 1800 \mathrm{IU}$; vitamin $\mathrm{E}, 60 \mathrm{mg}$; vitamin $\mathrm{K}, 1.5 \mathrm{mg}$; vitamin $\mathrm{B}_{1}, 1.5 \mathrm{mg}$; vitamin $\mathrm{B}_{2}, 6 \mathrm{mg}$; vitamin $B_{6}, 4 \mathrm{mg}$; vitamin $B_{12}, 25 \mathrm{mg}$; niacin, $40 \mathrm{mg}$; pantothenic acid, $16 \mathrm{mg}$; folic acid, $2 \mathrm{mg}$; biotin, $60 \mathrm{mg}$; choline chloride, $300 \mathrm{mg}$; Ca, $1.5 \mathrm{~g} ; 300 \mathrm{mg}$; Fe, $80 \mathrm{mg}$; Mn, 40 mg; Zn, 80 mg; Cu, 15 mg; I, 0.5 mg; Co, 0.5 mg; Se, 0.3 mg.

On day 30 of pregnancy, the sows were placed in the metabolism cages. The experiment lasted 12 days and consisted of four days for adaptation to the metabolism crates, followed by eight days of total collection of faeces. Faeces were collected daily from each sow in a bucket. Collection began at 07:30 in the morning on day 1 and ceased at 07:30 in the morning of day 9 of the collection period. Buckets were emptied once daily. The faeces were weighed and homogenized and a subsample ( $15 \%$ total faeces) was stored at $-20^{\circ} \mathrm{C}$. The frozen daily subsamples were then thawed and bulked together per sow. The content of crude protein was determined in the thawed samples. Other samples of faeces were oven-dried and finely ground for chemical analyses.

The basic chemical composition of diet and faeces samples was determined by standard methods (AOAC, 2007), namely dry matter by drying at $105^{\circ} \mathrm{C}$ to constant weight; ether extract by Soxhlet extraction with diethyl ether; crude ash by incineration in a muffle furnace at $580^{\circ} \mathrm{C}$ for $8 \mathrm{~h}$; crude protein $(\mathrm{N} \times 6.25)$, using the Kjeldahl method with the Büchi Distillation Unit B-324 (Büchi Labortechnik AG, Switzerland) and, Weende crude fibre on a ANCOM 220 fibre analyser (ANKOM Technology, USA). Starch content was determined with the Ewers polarimetric method (EEC, 1972), and the content of sugars was measured by the Luff-Schoorl method (BIPEA, 1976). Amino acids in the diet were determined on a Beckman 6300 amino acid analyser (Beckman Instruments Corp., Palo Alto, Calif, USA). Before analysis, samples were hydrolyzed with $6 \mathrm{M} \mathrm{HCl}$ for $24 \mathrm{~h}$ at $110^{\circ} \mathrm{C}$ [method $982.30 \mathrm{E}(\mathrm{a})$; AOAC, 2007]. Sulphur-containing amino acids (methionine and cystine) were determined as Met sulfone and cysteic acid after cold performic acid oxidation overnight before hydrolysis [method $982.30 \mathrm{E}(\mathrm{b})$; AOAC 2007]. Tryptophan was determined after $\mathrm{NaOH}$ hydrolysis for $22 \mathrm{~h}$ at $110^{\circ} \mathrm{C}$ [method $982.30 \mathrm{E}(\mathrm{c})$; AOAC, 2007]. Phosphorus was measured by the vanadium-molybdenum colorimetric method (Cavell, 1955) and calcium by emission spectrometry on a Buck Scientific 210 VGP atomic absorption spectrophotometer. 

formula:

Nitrogen-free extract (NFE) was calculated as:

NFE $(\%)=100-\%$ (moisture + ash + crude protein + ether extract + crude fibre) .

The apparent total tract digestibility (ATTD) of nutrients in the diet was calculated using the following

$\operatorname{ATTD}(\%)=[$ nutrient in feed - nutrient in faeces/nutrient in feed $] \times 100$.

The ME concentrations in the diets were calculated using the formula (Jentsch et al. 2003):

$\mathrm{ME}(\mathrm{MJ} / \mathrm{kg})=0.0205 \mathrm{dCP}+0.0398 \mathrm{dEE}+0.0173 \mathrm{dST}+0.0160 \mathrm{dSU}+0.0147 \mathrm{dNFR}$.

where $d N F R$ is digestible $N$-free residua $[\mathrm{dNFR}=\mathrm{dOM}-(\mathrm{dCP}+\mathrm{dEE}+\mathrm{dST}+\mathrm{dSU})$

$\mathrm{dCP}$ is digestible crude protein

$\mathrm{dEE}$ is digestible ether extract

dST is digestible starch

dSU is digestible sugars

dOM is digestible organic matter content in $\mathrm{g} / \mathrm{kg}$ feed.

The results are presented as arithmetic means $(\bar{X})$ and standard deviation (SD). The data were subjected to a one-way analysis of variance (ANOVA). The significance of difference $(P)$ between means was determined by using paired t-tests. Statistical data analysis was carried out using Statistica software (Statistica PL, version 10).

\section{Results}

The analysed chemical composition of the diet used in the study is given in Table 2, and the amino acids content in Table 3. The levels of organic matter, crude protein and crude fibre in the diet were 836.3, 145.8 and $76.5 \mathrm{~g} / \mathrm{kg}$, respectively. The indispensable amino acids were at levels that met or exceeded the estimated requirements for sows during early pregnancy (Polish Standards of Pig Feeding, 2014).

Table 2 Chemical composition of experimental diet for sows during early pregnancy

\begin{tabular}{lc}
\hline Chemical composition & $\mathbf{( g / \mathbf { k g } )}$ \\
\hline Dry matter & 887.0 \\
Ash & 50.7 \\
Organic matter & 836.3 \\
Crude protein & 145.8 \\
Ether extract & 33.8 \\
Crude fibre & 76.5 \\
Nitrogen-free extract & 583.6 \\
Starch & 397.1 \\
Sugars & 33.5 \\
Calcium & 7.95 \\
Phosphorus & 5.99 \\
\hline
\end{tabular}

The data presented in Table 4 indicate the effect of sow age on the apparent total tract digestibility of dry matter, organic matter, crude protein and crude fibre. Sows in the fourth pregnancy had greater digestibility coefficients of dry matter $(P<0.05)$, organic matter $(P<0.05)$ and crude protein $(P<0.01)$ than sows in the first pregnancy. However, the most pronounced difference between sows in the fourth and first pregnancy was in the digestibility of crude fibre $(+6.2$ percentage units; $P<0.01)$. There was no significant effect of sow age on the apparent total digestibility tract of other nutrients. 
Table 3 Amino acid composition of experimental diet for sows during early pregnancy

\begin{tabular}{lr}
\hline Amino acids & $\mathbf{( g / k g )}$ \\
\hline Indispensable amino acids & \\
Arginine & 8.31 \\
Histidine & 3.67 \\
Isoleucine & 4.81 \\
Leucine & 9.53 \\
Lysine & 6.84 \\
Methionine & 2.57 \\
Phenylalanine & 6.59 \\
Threonine & 5.30 \\
Tryptophan & 1.81 \\
Valine & 6.71 \\
Dispensable amino acids & \\
Alanine & 6.87 \\
Aspartic acid & 10.98 \\
Cystine & 2.45 \\
Glutamic acid & 29.21 \\
Glycine & 7.06 \\
Proline & 9.62 \\
Serine & 6.23 \\
Tyrosine & 4.29 \\
Total amino acids & 132.85 \\
\hline
\end{tabular}

Table 4 Mean ( \pm SD) of apparent total tract nutrient digestibility (\%) by gestating sows

\begin{tabular}{lccc}
\hline \multirow{2}{*}{ Nutrients } & \multicolumn{2}{c}{ Sow age } & \multirow{2}{*}{$\boldsymbol{P}$} \\
\cline { 2 - 3 } & first pregnancy $\bar{X} \pm$ SD & fourth pregnancy $\bar{x} \pm$ SD & \\
\hline Dry matter & $74.3 \pm 1.8$ & $78.4 \pm 1.5$ & $<0.05$ \\
Organic matter & $77.8 \pm 1.6$ & $81.2 \pm 1.3$ & $<0.05$ \\
Crude protein & $76.8 \pm 2.4$ & $82.3 \pm 2.1$ & $<0.01$ \\
Ether extract & $73.8 \pm 4.4$ & $75.6 \pm 4.1$ & NS \\
Crude fibre & $26.6 \pm 3.3$ & $32.8 \pm 2.9$ & $<0.01$ \\
Nitrogen-free extract & $84.0 \pm 1.8$ & $86.1 \pm 1.3$ & NS \\
Starch & $97.9 \pm 1.7$ & $98.7 \pm 2.1$ & NS \\
Sugars & $98.2 \pm 1.4$ & $99.1 \pm 1.5$ & NS \\
\hline
\end{tabular}

SD: standard deviation.

NS: not significant.

Differences in nutrient digestibility between sows in first and fourth pregnancy resulted in a higher content of digestible dry matter $(5.5 \%, P<0.05)$, digestible organic matter $(4.4 \% ; P<0.05)$, digestible protein (8.0\%; $P<0.01)$, and digestible crude fibre $(25.0 \% ; P<0.01)$ in the diet of sows the fourth pregnancy than in the first pregnancy (Table 5). Consequently, the metabolizable energy content in the diet of sows in the fourth pregnancy was $0.7 \mathrm{MJ} / \mathrm{kg}$ higher $(P<0.01)$ than in the diet of sows in the first pregnancy. 
Table 5 Comparison of the content of digestible nutrients and metabolizable energy in sow diet in the first and fourth pregnancies

\begin{tabular}{|c|c|c|c|c|}
\hline \multirow[b]{2}{*}{ Item } & \multicolumn{2}{|c|}{ Sow age } & \multirow{2}{*}{$\begin{array}{c}\text { Fourth pregnancy } \\
\text { relative to first } \\
\text { pregnancy } \\
(\%)\end{array}$} & \multirow[b]{2}{*}{$P$} \\
\hline & $\begin{array}{c}\text { first pregnancy } \\
\bar{X} \pm \mathrm{SD}\end{array}$ & $\begin{array}{l}\text { fourth pregnancy } \\
\qquad \bar{x} \pm \mathrm{SD}\end{array}$ & & \\
\hline \multicolumn{5}{|c|}{ Digestible nutrients (g/kg) } \\
\hline Dry matter & $659.0 \pm 13.0$ & $695.4 \pm 11.3$ & 105.5 & $<0.05$ \\
\hline Organic matter & $650.6 \pm 12.3$ & $679.1 \pm 11.0$ & 104.4 & $<0.05$ \\
\hline Crude protein & $112.0 \pm 3.6$ & $120.9 \pm 3.1$ & 108.0 & $<0.01$ \\
\hline Ether extract & $24.9 \pm 2.1$ & $25.8 \pm 1.7$ & 103.6 & NS \\
\hline Crude fibre & $20.4 \pm 2.6$ & $25.5 \pm 2.1$ & 125.0 & $<0.01$ \\
\hline Nitrogen-free extract & $489.6 \pm 9.4$ & $501.9 \pm 7.9$ & 102.6 & NS \\
\hline Starch & $388.0 \pm 5.9$ & $391.5 \pm 7.2$ & 100.9 & NS \\
\hline Sugars & $32.6 \pm 0.5$ & $33.0 \pm 0.6$ & 101.2 & NS \\
\hline $\begin{array}{l}\text { Metabolizable energy } \\
(\mathrm{MJ} / \mathrm{kg})\end{array}$ & $11.8 \pm 0.5$ & $12.5 \pm 0.4$ & 105.9 & $<0.01$ \\
\hline
\end{tabular}

SD: standard deviation.

NS: not significant.

\section{Discussion}

The experimental diet contained high levels of crude fibre. The early pregnancy of sows is the recommended period for feeding fibrous diets because their nutrient requirements in this period are lower than in those of growing pigs and lactating sows. Furthermore, dietary fibre can improve embryo survival (Jindal et al., 1996) and ovulation rate (Cox et al., 1987), ultimately increasing the litter size of sows at birth.

The current studies demonstrated that apparent total tract digestibility of dry matter, organic matter, crude protein and crude fibre were greater in sows in the fourth pregnancy than in the first pregnancy. Greater digestibility of dietary energy, $\mathrm{N}$ and fibre in multiparous sows than in nulliparous sows was also observed by Renteria-Flores et al. (2008). Other studies have shown that the apparent total tract digestibility of energy and several nutrients in adult sows was greater than in growing pigs (Fernández et al., 1986; Le Goff \& Noblet, 2001; Le Gall et al., 2009; Lowell et al., 2015).

The increased digestibility of nutrients by sows in the fourth pregnancy compared with sows in the first pregnancy might be the result of differences in age, body weight and time of adaptation to a high fibre diet. The body weight of pigs increases with age, correlating with larger, more developed intestinal tracts and thus greater intestinal volume (Brunsgaard, 1997; Le Goff \& Noblet, 2001; Landgraf et al., 2006). Additionally, a longer period of feeding a diet rich in fibre allows for an increase in the gastrointestinal tract of the pigs (Bridges et al., 1986; Rijnen et al., 2001). It could be assumed that in the current study the sows in the fourth pregnancy had greater gastrointestinal tracts owing to greater body weight and longer feeding time of a diet high in fibre than the sows in first pregnancy. Increased gastrointestinal tract volume may influence digestibility through a slower transit time of digesta and greater contact of endogenous enzymes and microbial populations and more absorption of nutrients in the small and large intestines (Fernández et al., 1986; Low, 1993; Le Goff et al., 2002). However, the improvement of digestibility with age results mainly from a larger microbial population and more extensive fermentation in the large intestine (Shi \& Noblet 1993a; b; Urriol et al., 2010).

The improved digestibility of crude fibre is particularly noticeable with age (Le Goff \& Noblet 2001; Lowell et al., 2015), which agrees with the results of this study. Shi \& Noblet (1993a) reported that fermentation of crude fibre in the large intestine is roughly $25 \%$ greater in sows than in growing pigs. Fermentation of crude fibre in the large intestine of pigs yields volatile fatty acids that can generate about $25 \%$ of the total digestible energy derived from the diet of sows (Shi \& Noblet, 1993b). This value in multiparous sows is likely to be higher than in nulliparous sows owing to their greater ability to digest fibrous feed ingredients.

These results indicate that the total tract digestibility of ether extract, starch and sugars is not dependent on the age of pigs, which is consistent with previous reports (Le Goff \& Noblet 2001; Serena et al., 
2008). These nutrients are digested mainly in the small intestine (Lin et al., 1987) with several differences between growing and adult pigs.

The value of ME of the diet of sows in fourth pregnancy was greater than that of the diet of sows in first pregnancy (Table 5). This suggests that the ability of sows to degrade and utilize the fibre fraction in the large intestine improves with age. Therefore, sow age should be considered when formulating and estimating the energy value of diets of sows during early pregnancy. An increase in the value of metabolizable energy in diet, depending on the age of the pig, was observed by other authors (Le Goff \& Noblet, 2001; Lowell et al., 2015).

\section{Conclusions}

Apparent total tract digestibility of dry matter, organic matter, crude protein and crude fibre was greater in sows in the fourth pregnancy than in the first. Consequently, the value of metabolizable energy, determined according to the content of digestible nutrients, in the diet of sows in the fourth pregnancy was greater than in the diet of sows in the first. Therefore, sow age must be considered when formulating and estimating the energy value of diets for sows during early pregnancy, because multiparous sows have greater ability to digest fibre fraction in the large intestine than nulliparous sows.

\section{Authors' Contributions}

E.J. and A.P. were responsible for experiment conception and design, supervision of project, interpretation of results and wrote the manuscript. W.B., M.K. and A.S. participated in perform the research, collating the result and statistical analysis of data. A. K-S. and B.M. were responsible for supervision and perform the research. All authors were involved in discussing and interpreting the results.

\section{Conflict of Interest Declaration}

None of the authors have any conflict of interest to declare.

\section{References}

AOAC, 2007. Association of Analytical Chemists. Official Methods of Analysis (18th ed. Rev.2). Eds: Hortwitz, W. \& Latimer Jr., G.W., AOAC International, Gaithersburg (MD).

BIPEA, 1976. Bureau Interprofessionnel d'Etude Analytique. Recueil des méthodes d'analyse des Communautés Européennes. Gennevilliers, France. pp. 105-111. (in French).

Bridges, T.C., Turner, L.W., Smith, E.M., Stahly, T.S. \& Loewer, O.J., 1986. A mathematical procedure for estimating animal growth and body composition. Am. Soc. Agric. Eng. 29, 1342-1347.

Brunsgaard, G., 1997. Morphological characteristics, epithelial cell proliferation, and crypt fission in cecum and colon of growing pigs. Dig. Dis. Sci. 42, 2384-2393.

Cavell, A.J., 1955. The colorimetric determination of phosphorus in plant materials. J. Sci. Food Agric. 6, 479-481.

Cox, N.M., Stuart, M.J., Althen, T.G., Bennett, W.A. \& Miller, H.W., 1987. Enhancement of ovulation rate in gilts by increasing dietary energy and administering insulin during follicular growth. J. Anim. Sci. 64, 507-516.

EEC, 1972. European Economic Community. Analytical determination of starch. In: Official Journal of European Communities Publishing, No. 123. Brussels, Belgium. pp. 4-7.

Fernández, J.A., Jørgensen, H. \& Just, A., 1986. Comparative digestibility experiments with growing pigs and adult sows. Anim. Prod. 43, 127-132.

Jindal, R., Cosgrove, J.R., Aherne, R.X. \& Foxcroft, G.R., 1996. Effect of nutrition on embryonal mortality in gilts: association with progesterone. J. Anim. Sci. 74, 620-624.

Jentsch, W., Chudy, A. \& Beyer, M., 2003. Rostock Feed Evaluation System: Reference numbers of feed value and requirement on the base of net energy. Plexus Verlag, Miltenberg-Frankfurt, Germany.

Jørgensen, H., Zhao, X. \& Eggum, B.O., 1995. The influence of dietary fibre and environmental temperature on the development of the gastrointestinal tract, digestibility, degree of fermentation in the hind-gut and energy metabolism in pigs. Br. J. Nutr. 75, 365-378.

Jørgensen, H., Serena, A., Hedemann, M.S. \& Bach Knudsen, K.E., 2007. The fermentative capacity of growing pigs and adult sows fed diets with contrasting type and level of dietary fibre. Livest. Sci. 109, 111-114.

Landgraf, S., Susenbeth, A., Knap, P.W., Looft, H., Plastow, G.S., Kalm, E. \& Roehe, R., 2006. Developments of carcass cuts, organs, body tissues, and chemical body composition during growth of pigs. Anim. Sci. 82, 889-899.

Le Gall, M., Warpechowski, M., Jaguelin-Peyraud, Y. \& Noblet, J., 2009. Influence of dietary fibre level and pelleting on the digestibility of energy and nutrients in growing pigs and adult sows. Anim. 3, 352-359.

Le Goff, G. \& Noblet, J., 2001. Comparative total tract digestibility of dietary energy and nutrients in growing pigs and adult sows. J. Anim. Sci. 79, 2418-2427.

Le Goff, G., Van Milgen, J. \& Noblet, J., 2002. Influence of dietary fibre on digestive utilization and rate of passage in growing pigs, finishing pigs and adult sows. Anim. Sci. 74, 503-515.

Lin, F.D., Knabe, D.A. \& Tanksley Jr., T.D., 1987. Apparent digestibility of amino acids, gross energy and starch in corn, sorghum, wheat, barley, oat groats and wheat middlings for growing pigs. J. Anim. Sci. 64,1655-1663.

Low, A.G., 1993. Role of dietary fiber in pig diets. In : Recent developments in pig nutrition, 2nd ed. Eds: Cole, D.J.A., Haresign, W. \& Garnsworthy, P.C., Nottingham, University Press, Loughborough, UK. pp. 137-162. 
Lowell, J.E., Liu, Y. \& Stein, H.H., 2015. Comparative digestibility of energy and nutrients in diets fed to sows and growing pigs. Arch. Anim. Nutr. 69, 79-97.

Mosenthin, R., 1998. Physiology of small and large intestine of swine -review-. Asian-Austral. J. Anim. Sci. 11, 608-619.

Noblet, J. \& Shi, X.S., 1993. Comparative digestibility of energy and nutrients in growing pigs fed ad libitum and adult sows fed at maintenance. Livest. Prod. Sci. 34, 137-152.

Polish Standards of Pigs Feeding, 2014. Institute of Animal Physiology and Nutrition, Polish Academy of Sciences, Warsaw, Poland. pp.1-94.

Renteria-Flores, J.A., Johnston, L.J., Shurson, G.C. \& Gallaher, D.D., 2008. Effect of soluble and insoluble fiber on energy digestibility, nitrogen retention, and fiber digestibility of diets fed to gestating sows. J. Anim. Sci. 86, 2568-2575.

Rijnen, M.M.J.A., Dekker, R.A., Bakker, G.C.M., Verstegen, M.W.A. \& Schrama, J.W., 2001. Effects of dietary fermentable carbohydrates on the empty weights of the gastrointestinal tract in growing pigs. In: Digestive Physiology of Pigs. Eds: Lindberg, J.E. \& Ogle, B., CABI Publishing, New York. pp. 17-20.

Serena, A., Jorgensen, H. \& Bach Knudsen, K.E., 2008. Digestion of carbohydrates and utilization of energy in sows fed diets with contrasting levels and physicochemical properties of dietary fiber. J. Anim. Sci. 86, 2208-2216.

Shi, X.S. \& Noblet, J., 1993a. Digestible and metabolizable energy values of ten feed ingredients in growing pigs fed ad libitum and sows fed at maintenance level; comparative contribution of the hindgut. Anim. Feed Sci. Technol. 42 , 223-236.

Shi, X.S. \& Noblet, J., 1993b. Contribution of the hindgut to digestion of diets in growing pigs and adult sows: effect of diet composition. Livest. Prod. Sci. 34, 237-252.

Urriola, P.E., Shurson, G.C. \& Stein, H.H., 2010. Digestibility of dietary fiber in distillers co-products fed to growing pigs. J. Anim. Sci. 88, 2373-2381.

Varel, V.H., 1987. Activity of fiber-degrading microorganisms in the pig large intestine. J. Anim. Sci. 65, 488-496.

Wilfart, A., Montagne, L., Simmins, P.H., Van Milgen. J. \& Noblet, J., 2007. Sites of nutrient digestion in growing pigs: Effect of dietary fiber. J. Anim. Sci. 85, 976-983. 